\title{
PRAKTINIO MOKYMO IR MENTORYSTĖS VAIDMUO UGDANT PACIENTŲ SAUGOS GEBĖJIMUS: SLAUGOS STUDIJŲ ATVEJIS
}

\author{
Simona Paulikienė \\ Klaipèdos universiteto Socialinès pedagogikos katedra
}

Raktažodžiai: praktinis mokymas, mentorystė, pacientų saugos gebejjimai, slaugos studijos.

\begin{abstract}
Santrauka
Pacientų sauga yra visuotinè visuomenès sveikatos problema. PSO duomenimis, milijonai pacientų visame pasaulyje kasmet patiria negalią sukeliančius sužalojimus ar mirtị dèl nesaugios medicinos praktikos ir slaugos. Pacientų saugos gebejjimai yra svarbūs profesinei praktinei veiklai, tačiau būsimų sveikatos priežiūros specialistų pacientų saugos mokymas, kaip rodo tyrimai, neatitinka sveikatos priežiūros sektoriaus poreikių. Straipsnyje pristatomo tyrimo tikslas - atskleisti praktinio mokymo ir mentorystės vaidmenį ugdant slaugos studentų pacientų saugos gebejjimus. Siekiant tikslo buvo atlikta apklausa, kurioje dalyvavo 276 bendrosios praktikos slaugos studiju programos studentai. Atliktas tyrimas atskleide, kad slaugos studentai rizikos valdymo, bendravimo su pacientais, aplinkos faktorių supratimo, saugos kultūros bei komandinio darbo gebejjimų ịgija daugiau teorinių užsièmimų nei praktinio mokymo metu. Praktinio mokymo metu studentai pacientų saugos gebejjimų igija nepakankamai. Tyrimo metu nustatyta, kad mentoriaus veikla yra svarbi ugdant slaugos studentų pacientų saugos gebejjimus.
\end{abstract}

\section{Ivadas}

Pacientų sauga - rizikos ir nepageidaujamų ivvykiu (susijusių su pacientu) atpažinimas, analizè ir valdymas, kad pacientų sveikatos priežiūra taptų saugesnè ir būtų kuo labiau sumažinta pacientams daroma žala (1). Pacientų sauga yra visuotinè visuomenès sveikatos problema. Pasaulinės sveikatos organizacijos (PSO) duomenimis, milijonai pacientų visame pasaulyje kasmet patiria negalią sukeliančius sužalojimus ar mirtį dèl nesaugios medicinos praktikos ir slaugos (2). Iš dalies tai sąlygota tuo, kad esamų ir būsimų sveikatos priežiūros specialistų pacientų saugos mokymas neatitinka sveikatos priežiūros sektoriaus poreikių (3-5).

Pacientų saugos gebėjimai yra svarbūs profesinès praktinès veiklos metu, todèl aktualu ịdiegti ir integruoti pacientų saugos klausimus sveikatos priežiūros specialistų mokyme $(6,7)$. Tačiau mokslinėje literatūroje nurodoma, kad trūksta tyrimų, kuriuose būtų nagrinèjama būsimų sveikatos priežiūros specialistų (studentų) nuomonè apie pacientų saugos mokymą(-si) studijų metu. Esami tyrimai rodo, kad pacientu saugos aspektai nei teorinio, nei praktinio mokymo metu nèra sistemingai plètojami kaip rekomenduoja PSO (7-10).

Svarbu atskirai vertinti pacientų saugos gebėjimų plètojimą abiejose - teorinio bei praktinio - mokymo ir mokymosi aplinkose, kadangi jos teikia labai skirtingas mokymo ir mokymosi patirtis ir dažnai tarp jų pasireiškia nesuderinamumas, žinomas kaip teorijos-praktikos atotrūkis (11-13). Būsimų sveikatos priežiūros specialistų pacientų saugos kompetencija gali būti ịgyjama, kai pacientų saugos žinios, ignudžiai ir nuostatos nuosekliai ir palaipsniui integruojamos visose mokymo ir mokymosi aplinkose.

Praktika yra labai svarbi pacientu saugos mokyme. Praktikos vadovas - mentorius - vaidina svarbų vaidmeni plètojant studentų žinias, igūdžius, požiūrius ir vertybes bei sukuria mokymuisi palankias situacijas. Jo tikslas - parodyti studentams, kada ir kaip pacientų saugos žinios gali būti taikomos praktikoje. Veiksminga mentoriaus veikla ir visų suinteresuotų pusių bendradarbiavimas ne tik sukuria produktyvesnę mokymosi aplinką, bet ir pagerina pacientų saugą $(2,13,14)$.

Kadangi sveikatos priežiūros specialistų pacientų saugos gebejjimai pradedami ugdyti studijų metu, tikslinga panagrinèti slaugos studentų nuomonę apie šių gebejjimų igijimą.

Sukurta nemažai tyrimo instrumentų, kurių pagalba galima vertinti studentų požiūrius, žinias, igūdžius apie pacientų saugą. Tačiau daugeliu atveju šie klausimynai buvo sukurti ir panaudoti ịvertinti konkrečių pacientų saugos curriculum ar praktinio mokymo intervencijų poveiki šiems gebėjimams $(15,16)$. 
Tuo tarpu šiame tyrime, skirtingai nei kitose atliktose studijose, nesiekiama tirti pacientų saugos gebejjimų, igytų konkrečiose sveikatos priežiūros srityse, o koncentruojamasi ị bendrą saugos gebejjimų turinį.

Tyrimo objektas - pacientų saugos gebejjimų ugdymas slaugos studijose.

Uždaviniai: palyginti pacientų saugos gebėjimus, igytus teorinių užsièmimų ir praktinio mokymo metu slaugos studijose; išsiaiškinti slaugos studentų nuomonę apie pacientų saugos gebejjimus, igytus praktinio mokymo metu; ištirti mentorystès ir slaugos studentų pacientų saugos gebejjimų koreliacinị ryšị.

Tikslas - atskleisti praktinio mokymo ir mentorystès vaidmenį ugdant slaugos studentų pacientų saugos gebėjimus.

\section{Tyrimo medžiaga ir objektas}

Šis tyrimas grindžiamas sistemų teorija, nes sveikatos priežiūros kokybè ir pacientų sauga turètų būti nagrinèjami sistemingai. Sisteminị požiūrị ị sveikatos priežiūrą nulemia jos kontekstas, kuriame galimi nepageidaujami ìvykiai ir klaidos. Tyrimai rodo, kad šiuos įvykius ir klaidas sukelia sistemos bei jos posistemių sutrikimai, nulemti įvairių veiksnių, o ne viena atskira priežastis $(2,7,17,18)$.

Remiantis sistemų teorija, pacientų saugą galima traktuoti kaip sistemą, sudarytą iš tarpusavyje susijusių posistemių - sričių. Pacientų sauga skirstoma ị šias pagrindines sritis $(2,6,17)$ :

Saugos kultūra. Ją sudaro individų ar grupių vertybès, požiūriai, suvokimas, kompetencijos ir elgesio modeliai, kurie nulemia organizacijos įsipareigojimą vykdyti tinkamą sveikatos priežiūrą ir saugą.

Rizikos valdymas. Esami ir būsimi sveikatos priežiūros specialistai turi būti sistemingai mokomi numatyti, priimti sprendimus ir valdyti situacijas, keliančias grèsmę pacientų saugai.

Žmogiškieji faktoriai. Šie faktoriai turi itakos santykiams tarp žmonių ir sveikatos priežiūros sistemos. Neatsižvelgimas ị žmogaus veiklos veiksnius yra esminė daugelio nepageidaujamų reiškinių sveikatos priežiūroje priežastis.

Komandinis darbas ir komunikacija. Sveikatos priežiūra retai atliekama pavienių asmenų. Saugi pacientų priežiūra priklauso ne tik nuo darbuotojų žinių, igūdžių ir elgesio, bet ir nuo to, kaip darbuotojai dirba komandoje konkrečioje darbo aplinkoje ir kaip komunikuoja tarpusavyje. Efektyvi komunikacija ypač svarbi siekiant optimalių gydymo ir slaugos rezultatų, o jos nepakankamumas gali sukelti žalą pacientui.

Nepageidaujamu juvykiu atpažinimas. Sveikatos priežiūros specialistai turi žinoti, kaip atpažinti nepageidauja- mus reiškinius ir laiku i juos reaguoti, siekiant užkirsti kelią tolesnei pacientų žalai.

Išskirtos pacientu saugos sritys yra universalios visoms sveikatos priežiūros sritims, todèl jos turi būti aptariamos ugdant būsimus sveikatos priežiūros specialistus ir tobulinant esamų specialistų pacientų saugos gebejjimus $(2,17,19)$. Šių gebėjimų ugdymui(si) studijų metu turi itakos aplinkos (mentoriaus veikla, klinikinès situacijos, medicininès priemonès ir kt.) faktoriai, studentu galimybès pritaikyti gebėjimus besikeičiančioms klinikinėms situacijoms, galimybè aptarti nepageidaujamus ịvykius ir kt. Taigi pacientų saugos gebejjimai sistemų teorijos požiūriu nagrinètini kaip galutiniai rezultatai.

Mentorystė yra vienas iš pagrindinių metodų, kurio pagalba ugdomas adekvatus, sistemingas pacientų saugos požiūris studentų praktinio mokymo metu, nes teorinių užsièmimų metu šiuos gebejjimus sunku igyti (20). Studentai kopijuoja ir modeliuoja mentoriaus elgesí, todèl studentų mokymasis klinikinès praktikos metu vyksta stebint mentoriaus veiklą. Mentorius veikia kaip elgesio modelis, tad jo veikla turi didelę ịtaką studentų elgesiui praktikos metu bei būsimoje profesinejje veikloje. Neadekvati mentoriaus saugos kultūra skatina formuotis neadekvačius studentų elgesio modelius $(2,7,13,14)$.

Tyrimo imtis. Empiriniam tyrimui pasirinktas bendrosios praktikos slaugos studijų programos atvejis (koleginès studijos). Lietuvoje bendrosios praktikos slaugytojus rengia 6 kolegijos (Kauno, Klaipėdos, Panevėžio, Šiaulių, Utenos ir Vilniaus). Imčiai suformuoti taikyta patogioji atranka - iš visų kolegijų buvo pasirinktos dvi ir jose 2012 lapkričio - 2013 vasario mèn. apklausti visi 3-4 kurso nuolatinių studijų studentai. Respondentais pasirinkti aukštesniųjų kursų studentai, nes jie yra išklausę didesnę dali teorinių dalykų bei atliko daugiau profesinès veiklos praktikų lyginant su žemesnių kursų studentais, todèl gali pateikti daugiau informacijos apie pacientu saugos gebejjimu igijimą. Tyrime dalyvavo $91 \mathrm{X}$ kolegijos ir $185 \mathrm{Y}$ kolegijos bendrosios praktikos slaugos studiju programos studentai $(N=276)$; iš ju 129 trečio kurso studentai (anketu grižtamumas 74,6 proc.) ir 147 ketvirto kurso studentai (anketų grižtamumas 95,5 proc.). Respondentų amžius svyravo nuo 20 iki $47 \mathrm{~m}$., amžiaus vidurkis - 22,9 m.

Tyrimo instrumentas. Klausimyną sudaro trys dalys.

Pirmoji dalis skirta sociodemografiniams duomenims apie respondentus nustatyti (respondentų amžius, kursas, aukštoji mokykla).

Antroji dalis. Šią autorinę klausimyno dalį sudaro 7 teiginiai, skirti išsiaiškinti studentų nuomonę apie mentoriaus veiklą praktinio mokymo asmens sveikatos priežiūros istaigose metu. Mentoriaus veiklą apibūdinantys teiginiai 
1 lentelè. Tyrimo metu gautas faktorinis sveikatos priežiūros specialistų pacientų saugos mokymo modelis

\begin{tabular}{|c|c|c|}
\hline Faktoriai/teiginiai & $\begin{array}{c}\text { Teiginių svoriai } \\
\text { faktoriuose }\end{array}$ & $\begin{array}{c}\text { Vidinis } \\
\text { suderinamumas }\end{array}$ \\
\hline \multicolumn{2}{|c|}{1 faktorius. Darbas komandoje su kt. sveik. priež. specialistais } & $\mathbf{0 , 8 4 2}$ \\
\hline 7. Nuomonès reiškimas ir parama & 0,716 & \\
\hline 6. Konfliktinių situacijų valdymas & 0,657 & \\
\hline 9. Bendradarbiavimas & 0,650 & \\
\hline 10. Komandos narių skatinimas viešinti & 0,618 & \\
\hline 5. Komandos vystymasis & 0,556 & \\
\hline 8. Paciento įtraukimas ị komandą & 0,768 & \\
\hline 21. Žmogiškųų faktorių vaidmuo pacientų saugai & 0,470 & \\
\hline \multicolumn{3}{|l|}{ Paaiškinama dispersija: 35,27 proc. } \\
\hline \multicolumn{2}{|l|}{2 faktorius. Saugos kultūra } & 0,726 \\
\hline 3. Sąlygų sudarymo svarba & 0,744 & \\
\hline 2. Veiksmų viešinimo svarba & 0,744 & \\
\hline 4. Sistemų prigimtis & 0,649 & \\
\hline 1. Kompleksinė sveikatos priežiūra & 0,589 & \\
\hline \multicolumn{3}{|l|}{ Paaiškinama dispersija: 6,54 proc. } \\
\hline \multicolumn{2}{|l|}{3 faktorius. Efektyvus komunikavimas } & 0,768 \\
\hline $\begin{array}{l}\text { 12. Pacientų saugos gerinimas bendraujant su sveik. priež. } \\
\text { specialistais }\end{array}$ & 0,747 & \\
\hline 13. Efektyvus bendravimas & 0,704 & \\
\hline 11. Pacientų saugos gerinimas bendraujant su pacientu & 0,542 & \\
\hline \multicolumn{3}{|l|}{ Paaiškinama dispersija: 6,36 proc. } \\
\hline \multicolumn{2}{|l|}{4 faktorius. Nepageidaujamų ịvykių atpažinimas } & 0,749 \\
\hline 22. Nepageidaujamų ịvykių viešinimas & 0,776 & \\
\hline 23. Dalyvavimas nepageidaujamų įvykių analizejje & 0,703 & \\
\hline 20. Nepageidaujamų ịvykių atpažinimas & 0,579 & \\
\hline 21. Tiesioginès grèsmès pacientų saugai sumažinimas & 0,563 & \\
\hline \multicolumn{3}{|l|}{ Paaiškinama dispersija: 5,80 proc. } \\
\hline \multicolumn{2}{|l|}{5 faktorius. Pacientų saugos rizikos valdymas } & 0,761 \\
\hline 15. Pacientų saugos sprendimų nustatymas & 0,777 & \\
\hline 16. Rizikos situacijų numatymas ir valdymas & 0,731 & \\
\hline 14. Pacientų saugos problemų atpažinimas & 0,624 & \\
\hline \multicolumn{3}{|l|}{ Paaiškinama dispersija: 5,12 proc. } \\
\hline \multicolumn{2}{|l|}{6 faktorius. Žmogiškųjų ir aplinkos faktorių supratimas } & $\mathbf{0 , 6 5 0}$ \\
\hline 18. Saugus sveikatos priežiūros technologijų taikymas & 0,797 & \\
\hline 19. Aplinkos faktorių vaidmuo pacientų saugai & 0,730 & \\
\hline Paaiškinama dispersija: 3,80 proc. & & \\
\hline
\end{tabular}

suformuoti atsižvelgiant ị pacientų saugos principus ir apėmė informacijos suteikimą, konstruktyvią kritiką, sietiną su pacientų sauga, paramą ịvykus nepageidaujamam ịvykiui, pagalbą plètojant pacientų saugos gebejjimus ir kt. Teiginiai buvo vertinami naudojant 5 rangų skalę, nuo teiginio ,visiškai nesutinku“ iki teiginio ,visiškai sutinku“.

Trečioji dalis sudaryta panaudojus dalị ,Sveikatos priežiūros specialistų pacientų saugos mokymo" klausimyno (H-PEPSS; angl. Health Professional Education in Patient Safety Survey), sukurto bendradarbiaujant Kanat dos Pacientų saugos institutui ir Yorku universitetui (8). Panaudotą klausimyno dali sudaro 6 sritys, kurias, savo ruožtu, sudarè nuo 3 iki 7 teiginiai (iš viso 23 teiginiai): saugos kultūra (4 teiginiai); darbas komandoje su kitais sveikatos priežiūros specialistais (6 teiginiai); efektyvus komunikavimas ( 7 teiginiai); pacientų saugos rizikos valdymas (3 teiginiai); žmogiškujų ir aplinkos faktorių supratimas (3 teiginiai); nepageidaujamų ìvykių atpažinimas, atsakas ir viešinimas (4 teiginiai). Detaliau šios sritys buvo aprašytos teorinèje straipsnio dalyje. Respondentų klausta, 
ar jie ịgijo ir plètojo pacientų saugos gebejjimus nurodytose temose teorinių užsièmimų ir praktinio mokymo metu. Originalioje anketoje kiekvienas teiginys vertinamas 5 rangu skale, tačiau šiame tyrime dèl kalbos ir kultūrinių aspektų buvo pasirinkta 3 rangų skalè: „Deja, neigijau“, „Iš dalies igijau“, „Igijau“.

L. R. Ginsburg, E. Castel ir kt. atliktame tyrime taip pat buvo panaudotas H-PEPSS klausimynas. Tyrimo rezultatai parodè šio modifikuoto 6 faktorių klausimyno validumą (19).

Pirminị klausimyno „Sveikatos priežiūros specialistų pacientų saugos mokymo" vertimą atliko tyrèja. Nesuradus lingvistinio atitikmens, kai kurios sąvokos išverstos netiesiogiai, t.y. vartojant panašius žodžius ir frazes. Vèliau versta anketa buvo pateikta patikrinti anglų kalbos specialistui. Atsižvelgus ị pateiktas pastabas, anketa pakoreguota ir pateikta bendrosios praktikos slaugos studijų programos studentams $(N=15)$. Po žvalgomojo tyrimo kai kurių teiginių formuluotès buvo kiek patikslintos bei parengtas galutinis klausimyno variantas.

Klausimyno patikimumui vertinti naudotas vidinio suderinamumo matas Cronbach'o $\alpha$ (alpha) koeficientas. Nagrinejjant vidinį subskalių suderinamumą nustatyta, kad subskalès „Teorinių užsièmimų metu ịgyti gebèjimai““ Cronbach'o a (alpha) koeficientas lygus 0,893, subskalès „Praktinio mokymo metu igyti gebejjimai“ - 0,907 ir subskalès „Mentoriaus veikla“ - 0,830. Taigi vidinis subskalių suderinamumas yra geras ir klausimynas naudotinas tolimesniems tyrimams.

Struktūrinis ,Sveikatos priežiūros specialistų pacientų saugos mokymo" klausimyno lietuviškos versijos validumas buvo tikrinamas atliekant originalaus klausimyno faktorių modelio patvirtinančiają analizę. Prieš atliekant faktorinę analizę, subskalių „Teorinių užsièmimų metu igyti gebejjimai“ ir „Praktinio mokymo metu igyti gebejjimai“ analogiški teiginiai transformuoti ị išvestinius kiekybinius kintamuosius. Atliekant faktorinę analizę buvo išnagrinèta kintamųų koreliacijų matrica. Dėl aukštos kintamuju koreliacijos (kuri svyruoja nuo 0,823 iki 0,943 ) iš klausimyno nebuvo pašalintas nei vienas kintamasis. Ivertinus Bartlett'o kriterijų $\left(\chi^{2}=2434,726 ; \mathrm{df}=253 ; p=0,000\right)$ bei $K M O$ kriteriju $(0,903)$ teigtina, kad koreliacinè matrica yra tinkama faktorinei analizei. Atliekant faktorinę analizę pasirinktas pagrindinių komponenčių metodas, Varimax vektorių pasukimas. Ištraukti 6 faktoriai, paaiškinantys 63,281 proc. bendrosios kintamuju dispersijos. Ivertinus gautų faktorių struktūrą nustatyta, kad teiginys ,Žmogiškujų faktorių vaidmuo pacientų saugai“" pateko ị kito faktoriaus, nei originaliame klausimyne, teiginių grupę (minètasis teiginys originaliame klausimyne priklause faktoriui „Žmogiškujų ir aplinkos faktorių supratimas“). Likusių teiginiu pasiskirstymas pagal faktorius (sritis) atitinka originalios anketos teiginių pasiskirstymą.

Taigi atlikta patvirtinančioji faktorinè analizė patvirtino i anketą îtrauktų teiginių reikšmingumą (faktorinis teiginių svoris nuo 0,470 iki 0,797 ) bei originalaus klausimyno autorių nustatytą faktorinį modeli su vieno teiginio neatitikimu (1 lentelè).

Duomenų analizė. Duomenu statistinè analizè buvo atlikta naudojant SPSS (Statistical Package for the Social Science) paketą, versija 17.0. Aprašomosios statistikos metodais apskaičiuotos įvairių rodiklių skaitinès charakteristikos (dažniai, vidurkiai), panaudoti neparametrinès statistikos metodai (Kolmogorov - Smirnov testas taikytas kintamujų skirsnių normalumui nustatyti, Wilcoxon kriterijus taikytas palyginti gebejimams tiriamojoje grupeje, Spearmen'o koreliacijos koeficientas panaudotas ryšio stiprumui ir pobūdžiui nusakyti). Statistiškai patikimas ryšys laikomas tada, kai $p$ reikšmè mažesnè už pasirinkto reikšmingumo lygmeni $(\alpha<0,05)$.

Tyrimo ribotumai. Tyrimo rezultatai dèl imties suformavimo ypatumų neturètų būti taikomi apibendrintai visų Lietuvos kolegijų bei universitetų mastu. Tačiau jais remiantis galima numatyti tam tikras tendencijas, svarbias j̣žvalgas pacientų saugos gebejjimų ugdymo plètojimui.

\section{Tyrimo rezultatai}

Teorinių užsiẻmimų ir praktinio mokymo metu igytų pacientų saugos gebėjimų palyginimas. Lyginant pacientų saugos gebejjimus nustatyti statistiškai reikšmingi skirtumai tarp teorinių užsièmimų ir praktinio mokymo metu igytų gebejjimų šiose srityse: „Saugos kultūra“, „Darbas komandoje su kitais sveikatos priežiūros specialistais", „Efektyvus komunikavimas“, „Pacientų saugos rizikos valdymas“, „Žmogiškujų ir aplinkos faktorių supratimas“.

Respondentų nuomone, pacientų saugos gebejjimų jie igija daugiau teorinių užsièmimų nei praktinio mokymo metu (2 lentelejje statistiškai reikšmingi skirtumai išryškinti tamsintu šriftu). Galima pastebèti, kad daugiausia skirtumų tarp teorinių užsièmimų ir praktinio mokymo metu igytų pacientų saugos gebejjimų iškilo dviejose gebejjimų grupèse: „Darbas komandoje su kitais sveikatos priežiūros specialistais“ (4 teiginiai iš 6 ) bei „Saugos kultūra“ (2 teiginiai iš 4). Statistiškai reikšmingi skirtumai tarp teorinių užsièmimų ir praktinio mokymo metu igytų pacientų saugos gebejjimų nenustatyti tik vienoje gebejjimų grupèje - „Nepageidaujamų ịvykių atpažinimas" (2 lentelè).

Šio tyrimo metu gauti rezultatai dera su kitų mokslinių tyrimų rezultatais, atskleidžiančiais, kad slaugos studentai praktinio mokymo metu lyginant su teoriniais užsièmimais igijo mažiau šių pacientų saugos gebėjimų: pacientų sau- 
2 lentelè. Praktinio mokymo ir teorinių užsiėmimų metu įgytų pacientų saugos gebėjimų vertinimas

\begin{tabular}{|c|c|c|c|c|c|c|c|c|}
\hline \multirow[t]{2}{*}{ Teiginiai } & \multirow{2}{*}{$\begin{array}{l}\text { Mokymo } \\
\text { forma }\end{array}$} & \multirow{2}{*}{$\begin{array}{l}Z \text { reikš- } \\
\text { mé }\end{array}$} & \multirow{2}{*}{$\begin{array}{l}p \text { reikš- } \\
\text { mè }\end{array}$} & \multirow{2}{*}{$\begin{array}{l}r \text { reikš- } \\
\text { mé }\end{array}$} & \multirow{2}{*}{$\begin{array}{l}\text { Rango } \\
\text { vidurkis }\end{array}$} & \multicolumn{3}{|c|}{ Gebèjimai (proc.) } \\
\hline & & & & & & $\begin{array}{l}\text { Neigi- } \\
\text { jau }\end{array}$ & $\begin{array}{l}\text { Iš dalies } \\
\text { igijau }\end{array}$ & Igijau \\
\hline \multicolumn{9}{|l|}{ Sritis: Saugos kultūra } \\
\hline \multirow{2}{*}{$\begin{array}{l}\text { Kompleksinė sveikatos } \\
\text { priežiūra }\end{array}$} & Praktika & \multirow[t]{2}{*}{$-1,051$} & \multirow[t]{2}{*}{0,293} & \multirow[t]{2}{*}{$-0,063$} & 36,59 & 8,9 & 59,3 & 31,8 \\
\hline & Teor.užs. & & & & 40,13 & 6,1 & 61,6 & 32,3 \\
\hline \multirow[t]{2}{*}{ Veiksmų viešinimo svarba } & Praktika & \multirow[t]{2}{*}{$-2,861$} & \multirow[t]{2}{*}{0,004} & \multirow[t]{2}{*}{$-0,172$} & 37,94 & 10,4 & 46,2 & 43,4 \\
\hline & Teor.užs. & & & & 40,32 & 7,4 & 42,9 & 49,6 \\
\hline \multirow[t]{2}{*}{ Sąlygų sudarymo svarba } & Praktika & \multirow[t]{2}{*}{$-4,671$} & \multirow[t]{2}{*}{0,000} & $-0,281$ & 32,80 & 15,3 & 48,0 & 36,7 \\
\hline & Teor.užs. & & & & 35,61 & 7,3 & 47,1 & 45,6 \\
\hline Sistemų prigimtis & Praktika & $-1,051$ & 0,293 & $-0,063$ & 29,32 & 14,7 & 56,1 & 29,1 \\
\hline & Teor.užs. & & & & 29,64 & 11,6 & 60,4 & 28,0 \\
\hline $\begin{array}{l}\text { Sritis: Darbas komandoje su } \\
\text { kt. sveik. priež. spec. }\end{array}$ & & & & & & & & \\
\hline Komandos vystymasis & Praktika & $-1,683$ & 0,092 & $-0,101$ & 47,27 & 10,4 & 38,4 & 51,3 \\
\hline & Teor.užs. & & & & 53,04 & 5,0 & 42,1 & 52,9 \\
\hline Konfliktinių situacijų valdymas & Praktika & $-0,161$ & 0,872 & $-0,009$ & 39,28 & 17,6 & 51,1 & 31,3 \\
\hline & Teor.užs. & & & & 40,78 & 19,6 & 48,2 & 32,1 \\
\hline Nuomonès reiškimas ir parama & Praktika & $-3,390$ & 0,001 & $-0,204$ & 39,54 & 17,2 & 48,7 & 34,1 \\
\hline & Teor.užs. & & & & 43,19 & 11,0 & 48,8 & 40,2 \\
\hline Paciento ịtraukimas į komandą & Praktika & $-3,399$ & 0,001 & $-0,205$ & 40,08 & 8,5 & 43,4 & 48,0 \\
\hline & Teor.užs. & & & & 42,16 & 4,3 & 39,8 & 55,9 \\
\hline Bendradarbiavimas & Praktika & $-4,684$ & 0,000 & $-0,282$ & 46,07 & 22,7 & 50,5 & 26,7 \\
\hline & Teor.užs. & & & & 47,31 & 13,3 & 49,1 & 37,6 \\
\hline Komandos skatinimas viešinti & Praktika & $-3,004$ & 0,003 & $-0,181$ & 43,84 & 16,7 & 46,7 & 36,6 \\
\hline & Teor.užs. & & & & 47,17 & 10,0 & 48,6 & 41,4 \\
\hline Žmogiškujų faktorių vaidmuo & Praktika & $-0,436$ & 0,663 & $-0,026$ & 39,55 & 7,9 & 45,7 & 46,4 \\
\hline pacientų saugai & Teor.užs. & & & & 39,45 & 6,4 & 47,7 & 45,9 \\
\hline $\begin{array}{l}\text { Sritis: Efektyvus } \\
\text { komunikavimas }\end{array}$ & & & & & & & & \\
\hline Pacientų saugos gerinimas & Praktika & $-2,371$ & 0,018 & $-0,143$ & 48,95 & 9,7 & 36,1 & 54,2 \\
\hline bendraujant su pacientais & Teor.užs. & & & & 49,08 & 6,4 & 32,7 & 60,9 \\
\hline Pacientų saugos gerinimas & Praktika & $-1,287$ & 0,198 & $-0,077$ & 42,59 & 10,3 & 45,6 & 44,1 \\
\hline bendraujant su sv. priež. spec. & Teor.užs. & & & & 50,07 & 9,0 & 41,6 & 49,5 \\
\hline Efektyvus bendravimas & Praktika & $-1,039$ & 0,299 & $-0,062$ & 42,84 & 9,3 & 42,9 & 47,9 \\
\hline & Teor.užs. & & & & 39,67 & 7,5 & 42,3 & 50,2 \\
\hline $\begin{array}{l}\text { Sritis: Pacientų saugos rizikos } \\
\text { valdymas }\end{array}$ & & & & & & & & \\
\hline Pacientu saugos problemų & Praktika & $-0,459$ & 0,646 & $-0,027$ & 38,87 & 11,2 & 57,2 & 31,7 \\
\hline atpažinimas & Teor.užs. & & & & 33,78 & 10,4 & 57,0 & 32,6 \\
\hline Pacientų saugos sprendimų & Praktika & $-1,429$ & 0,153 & $-0,086$ & 44,91 & 10,8 & 47,3 & 41,9 \\
\hline nustatymas & Teor.užs. & & & & 42,53 & 7,9 & 47,1 & 45,0 \\
\hline Rizikos situacijų numatymas ir & Praktika & $-2,875$ & 0,004 & $-0,173$ & 40,19 & 22,3 & 52,5 & 25,2 \\
\hline valdymas & Teor.užs. & & & & 41,15 & 15,6 & 54,3 & 30,1 \\
\hline $\begin{array}{l}\text { Sritis: Žmog. ir aplinkos } \\
\text { faktorių supratimas }\end{array}$ & & & & & & & & \\
\hline Saugus sveikatos priežiūros & Praktika & $-0,107$ & 0,915 & $-0,060$ & 38,03 & 8,2 & 39,8 & 52,0 \\
\hline technologijų taikymas & Teor.užs. & & & & 37,97 & 6,8 & 42,9 & 50,4 \\
\hline Aplinkos faktorių vaidmuo & Praktika & $-3,142$ & 0,002 & $-0,189$ & 37,19 & 11,9 & 49,8 & 38,3 \\
\hline pacientų saugai & Teor.užs. & & & & 36,59 & 6,8 & 49,3 & 43,9 \\
\hline $\begin{array}{l}\text { Sritis: Nepageidaujamų } \\
\text { ịvykių atpažinimas }\end{array}$ & & & & & & & & \\
\hline Nepageidaujamų įvykių & Praktika & $-1,638$ & 0,101 & $-0,098$ & 36,60 & 13,5 & 54,1 & 32,4 \\
\hline atpažinimas & Teor.užs. & & & & 31,67 & 11,1 & 52,7 & 36,2 \\
\hline Tiesioginès grèsmės pacientų & Praktika & $-1,287$ & 0,198 & $-0,077$ & 41,12 & 8,2 & 49,3 & 42,5 \\
\hline saugai sumažinimas & Teor.užs. & & & & 39,36 & 7,0 & 43,4 & 49,6 \\
\hline Nepageidaujamų įvykių & Praktika & $-1,705$ & 0,088 & $-0,102$ & 36,60 & 21,8 & 46,4 & 31,8 \\
\hline viešinimas & Teor.užs. & & & & 31,67 & 19,1 & 45,7 & 35,3 \\
\hline
\end{tabular}


gos kultūros, bendravimo su pacientais, komandinio darbo $(6,21)$.

Slaugos studentų nuomonė apie praktinio mokymo metu igytus pacientų saugos gebẻjimus. Išsamūs tyrimo rezultatai, atskleidžiantys studentų nuomonę apie pacientų saugos gebejjimų igijimą praktikos metu, pateikti 2 lentelèje. Aiškumo dèlei joje yra paryškinti gebėjimų, kurių igijimą arba neigijimą nurode didžiausia dalis visų respondentų, procentinès išraiškos.

Praktikos metu daugiausia ịgyjama pacientų saugos gerinimo bendraujant su pacientais gebejjimų - tai pažymèjo 54,2 proc. respondentų. Nežymiai mažesnè respondentų dalis nurodo įgijusi šiuos pacientų saugos gebejjimus: saugus sveikatos priežiūros technologijų taikymas (52,0 proc.), supratimas apie komandos vystymąsi (51,3 proc.), paciento įtraukimas ị komandą ( 48,0 proc.), efektyvus bendravimas (47,9 proc.), žmogiškujų faktorių vaidmuo pacientų saugai (46,4 proc.).

Tyrimo rezultatai atskleidè, kad daugiausia, tai yra 26,9 proc. respondentu praktikos metu neigyja dalyvavimo analizuojant nepageidaujamus ịvykius gebejjimų. Penktadalis studentų pažymi neigiję bendradarbiavimo ( 22,7 proc.), rizikos situacijų numatymo (22,3 proc.), nepageidaujamų ivykių viešinimo (21,8 proc.), konfliktinių situacijų valdymo (17,6 proc.) bei nuomonès reiškimo (17,2 proc.) gebejjimų.

Gauti tyrimo rezultatai atitinka tyrimų rezultatus, kuriuose taip pat nustatyta, kad studentai daugiausia igijo komunikavimo su pacientais $(12,21)$, saugaus medicinos technologijų taikymo (21) gebejjimų.

Šio tyrimo metu gauti rezultatai dera su tais tyrimų rezultatais, kuriuose nustatyti nepakankami slaugos studentu gebejjimai bendradarbiauti su asmens sveikatos priežiūros specialistais, pacientu (20), nepakankamas gebejjimų numatant rizikos faktorius, kaip viešinti nepageidaujamus ịvykius igijimas $(12,22)$, nepakankamas gebejjimas analizuoti nepageidaujamus ịvykius (21).

Viena iš priežasčių, sąlygojančių nepakankamą pacientų saugos gebéjimų igijimą praktinio mokymo metu, yra ta, kad pacientų sauga yra sąlyginai nauja sritis, todèl dalis mentorių nežino, kaip integruoti pacientų saugos mokymą (-si) i egzistuojanti curriculum. Kaip rodo tyrimai, vienas iš sunkumų, diegiant pacientų saugos temas i naujas mokymo programas, yra nenoras gilintis i ne biomedicinos srities žinias, tokias kaip sisteminis mąstymas ir kokybès gerinimo metodai $(23,24)$. Be to, kaip atskleide tyrimai, stu- dentai gali bijoti pateikti juos dominančius klausimus mentoriui, tuo suponuodami žinių ,spragą" tam tikrais pacientų saugos klausimais (20). Tokiu būdu mentorius neturi galimybès nustatyti studentų ịgtų gebẻjimų lygị, padèti ịgyti tinkamus pacientų saugos gebejimus, užmegzti veiksmingą abipusị bendravimą ir bendradarbiavimą.

Mentorystės ir pacientų saugos gebėjimų ugdymo sąryšis. Mentorystès ir pacientu saugos gebėjimų sąryšiui nustatyti buvo panaudoti subskalès „Praktinio mokymo metu igyti gebejjimai“" praktinio mokymo metu igyti pacientų saugos gebèjimai ir mentoriaus veiklą apibūdinančių teiginių išvestiniai kiekybiniai kintamieji. Tačiau, prieš nustatant koreliacini ryši tikslinga konstatuoti, kaip slaugos studentai vertina atskiras mentoriaus veiklas.

Tyrimo rezultatai, pateikti 1 pav., rodo, kad 52,5 proc. respondentų jaučiasi saugiai informuodami mentorių apie padarytas klaidas, sietinas su pacientu sauga, 53,8 proc. jaučia mentoriaus paramą priimant sprendimus, sietinus su pacientų sauga, 53,1 proc. sulaukia konstruktyvios mentoriaus kritikos, 60,8 proc. aptaria nepageidaujamą įvykị su mentoriumi. Pagalbos plètojant pacientų saugos gebejjimus iš mentoriaus sulaukia 72,5 proc. studentų, adekvačią informaciją apie pacientų saugą gauna 67,5 proc. tiriamųų Net 76 proc. respondentų nurodè, kad praktinio mokymo metu mentorius demonstruoja saugios praktikos principus. Tačiau nemaža dalis (24,3 proc.) slaugos studentų nesijaučia saugiai informuodami mentorių apie padarytas klaidas, sietinas su pacientų sauga.

Subskalès „Praktinio mokymo metu igyti gebejjimai“ ir mentoriaus veiklos išvestiniams kintamiesiems pritaikius Kolmogorov-Smirnov kriterijų nustatyta, kad išvestinių kintamuju skirstiniai neatitinka normaliojo pasiskirstymo $(\mathrm{p}<\mathrm{a}=0,05)$, todèl koreliacinei analizei atlikti pasirinks

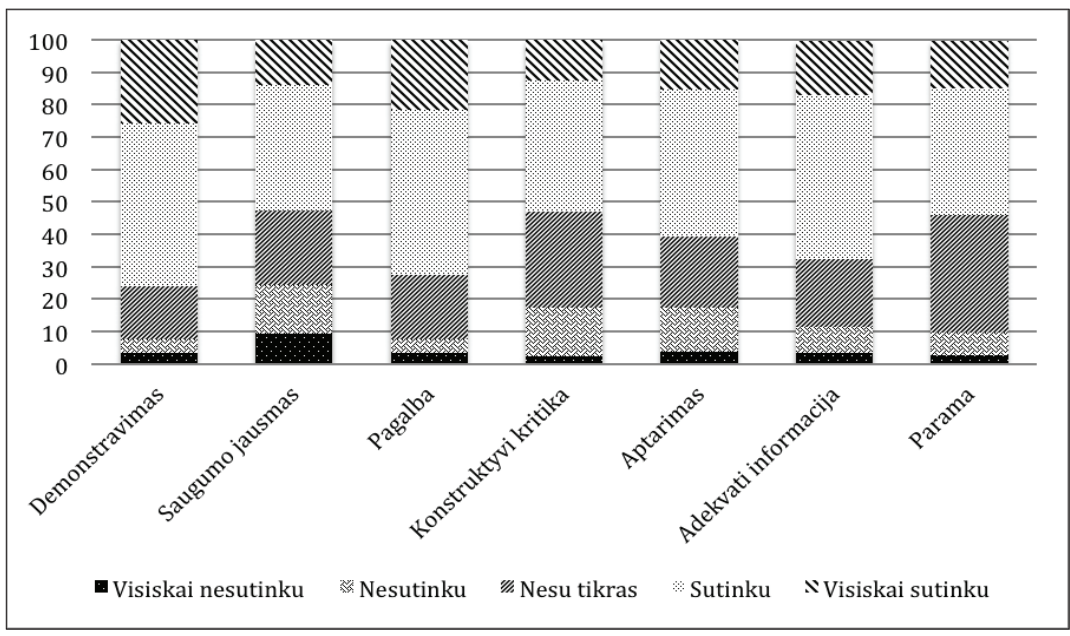

1 pav. Studentų nuomonė apie mentoriaus veiklą (proc.). 
3 lentelè. Koreliacinis ryšys tarp mentoriaus veiklos ir praktinio mokymo metu ịgytų pacientų saugos gebejjimų

\begin{tabular}{|l|l|l|}
\hline \multirow{2}{*}{ Sritis } & \multicolumn{2}{c|}{ Mentoriaus veikla } \\
\cline { 2 - 3 } & $p$ reikšmé & $r$ reikšmé \\
\hline Saugos kultūra & 0,000 & 0,306 \\
\hline $\begin{array}{l}\text { Darbas komandoje su kt. sveik. priež. } \\
\text { specialistais }\end{array}$ & 0,000 & 0,410 \\
\hline Efektyvus komunikavimas & 0,000 & 0,310 \\
\hline Pacientų saugos rizikos valdymas & 0,000 & 0,309 \\
\hline $\begin{array}{l}\text { Žmogiškujų ir aplinkos faktorių } \\
\text { supratimas }\end{array}$ & 0,000 & 0,255 \\
\hline Nepageidaujamų įvykių atpažinimas & 0,000 & 0,331 \\
\hline
\end{tabular}

tas Spearmen 'o koreliacijos koeficientas. Reiketų atkreipti dèmesí, kad naudotas koeficientas neleidžia spręsti apie priežastingumo ryšius ar krypti, o nustatyti ryšiai yra tikimybiniai.

Atlikta analizé rodo, kad koreliacija tarp praktinio mokymo metu igytu gebejimų bei mentoriaus veiklos yra statistiškai reikšminga (3 lentelè). Todèl galima teigti, kad mentoriaus veikla glaudžiai susijusi su pacientų saugos gebejjimu igijimu: kuo kokybiškesnè mentoriaus veikla, tuo studentai igija daugiau pacientų saugos gebejjimų praktinio mokymo metu.

Nustatytas teigiamas koreliacinis ryšys tarp mentoriaus veiklos kokybės ir visų pacientų saugos gebėjimų sričių. Stipriausias ryšys sieja mentoriaus veiklą ir studentų igytus darbo komandoje su kitais sveikatos priežiūros specialistais gebejjimus, palyginti silpnesnis - mentoriaus veiklą bei igytus žmogiškujų ir aplinkos faktorių supratimo gebejjimus.

\section{Išvados}

1. Atliktas tyrimas atskleide, kad slaugos studentai rizikos valdymo, bendravimo su pacientais, aplinkos faktoriu supratimo, saugos kultūros bei komandinio darbo gebejjimy igija daugiau teorinių užsièmimų nei praktinio mokymo metu.

2. Tyrimo rezultatai parodè, kad didžiausią respondentų dali, praktinio mokymo metu įgijusią pacientų saugos gebejjimus, sudare tik puse tyrimo dalyvių. Todèl galima teigti, kad praktinio mokymo metu slaugos studentai pacientu saugos gebejjimų igija nepakankamai.

3. Mentoriaus veikla yra svarbi plètojant slaugos studentų pacientų saugos gebėjimus praktinio mokymo metu. Kuo kokybiškesnè mentoriaus veikla, tuo studentai igija daugiau gebejjimų praktinio mokymo metu.

\section{Literatūra}

1. Terminų, susijusių su pacientų ir medikamentų sauga, žodynèlis. (http://www. vaspvt.gov. 1t/files/files/Zodynas_LT.pdf)
(2012-02-10)

2. WHO Patient Safety Curriculum Guide for Medical Schools. World Health Organization, 2009.

3. Andermann A, Ginsburg L, Norton P, Arora N, Bates D, Wu A, Larizgoitia I. Core competencies for patient safety research: a cornerstone for global capacity strengthening. BMJ Qual Saf. 2011;20:96-101.

4. Johnstone MJ, Kanitsake O. Clinical risk management and patient safety education for nurses: a critique. Nurse Education Today. 2007;27(3):185-191.

5. Patey R, Flin R, Cuthbertson BH, MacDonald L, Mearns K, Cleland J, Williams D. Patient safety: helping medical students understand error in healthcare. Quality \& Safety in Health Care. 2007; 16:256-259.

6. Ginsburg LR, Tregunno D, Norton PG. Self-reported patient safety competence among new graduates in medicine, nursing and pharmacy. BMJ Qual Saf. 2012;1-8. doi:10.1136/ bmjqs-2012-001308

7. Kiliam LA, Montgomery P, Raymond JM, Mossey S, Timmermans KE, Binette J. Unsafe clinical practices as perceived by final year baccalaureate nursing students: Q methodology. BMC Nursing. 2012;11:26 doi:10.1186/1472-6955-11-26

8. Castel E, Ginsburg L. Patient safety in health professional education: development of a questionnaire to asses student learning. http://www.yorku.ca/patientsafety/H-PEPSS/ 2008 pilot_Ginsburg\%20\&\%20Castel\%20Safety\%20Competencies\%20Studentship\%20Final\%20Report.pdf(2012-10-01)

9. Ginsburg LR, Chuang PG, Norton W, Berta D, Tregunno D, Richardson J. Development of a measure of learning from patient safety events. Health Serv Res. 2009;44(6): 2123-2147.

10. Neudorf K, Dyck N, Scott D, Davidson D. Nursing education: a catalyst for the patient safety movement. Health Q. 2008;11(3):35-39.

11. Armstrong GE, Spencer TS, Lenburg CB. Using quality and safety education for nurses to enhance competency outcome performance assessment: a synergistic approach that promote patient safety and quality outcomes. J Nurs Educ. 2009;48:686693.

12. Sherwood G. Integrating quality and safety science in nursing education and practice. Journal of Research in Nursing. 2011;16(3):226-240.

13. Vaismoradi M, Salsali M, Marck P. Patient safety: nursing students' perspectives and the role of nursing education to provide safe care. Int Nurs Rev. 2011;58:434-442.

14. Ross PT, McMyler ET, Anderson SG, Saran KA, UrteagaFuentes A, Boothman RC, Lypson ML. Trainees' Perceptions of Patient Safety Practices: Recounting Failures of Supervision. The Joint Commission Journal on Quality and Patient Safety. 2011;37(2):88-95.

15. Hobgood C, Sherwood G, Frush K. Teamwork training with nursing and medical students: does the method matter? Results of an interinstitutional, interdisciplinary collaboration. Qual Saf Health Care. 2010;19(6):1-6. 
16. Madigosky WS, Headrick LA, Nelson K. Changing and sustaining medical students' knowledge, skills, and attitudes about patient safety and medical fallibility. Acad Med. 2006;81:94-101.

17. The Safety Competencies. Enhancing Patient Safety Across the Health Professions. Canadian Patient Safety Institute, 2008.

18. Meyer RM, O’Brien-Pallas LL. Nursing Services Delivery theory: an open system approach. J Adv Nurs. 2010;66(12):28282838.

19. Ginsburg LR, Castel E, Tregunno D, Norton PG. The H-PEPSS: an instrument to measure health professionals' perceptions of patient safety competenceat entry into practice. BMJ Quality \& Safety. 2012;1-9. http://www. qualitysafety.bmj.com (201210-01)

20. Luhanga F, Yonge O, Myrick F. Hallmarks of Unsafe Practice. Journal for nurses in staff development. 2008;24(6):257-264.

21. Sullivan DT, Hirst D, Cronenwett L. Assessing quality and safety competencies of graduating prelicensure nursing students. Nurs Outlook. 2009;57:323-331.

22. White AA, Gallagher TH, Krauss MJ. The Attitudes and Experiences of Trainees Regarding Disclosing Medical Errors to Patients. Acad Med. 2008;83:250-256.

23. Sandars J, Bax N, Mayer D, Wass V, Vickers R. Educating undergraduate medical students about patient safety: priority areas for curriculum development. Medical Teacher. 2007; 29(1):60-61.

24. Walton M. Teaching patient safety to clinicians and medical students. The Clinical Teacher. 2007;4(4):224-231.

\section{PRACTICAL TRAINING AND MENTORING IN DEVELOPING PATIENT SAFETY COMPETENCIES: NURSING STUDIES CASE \\ S.Paulikienè}

Key words: practical training, mentoring, competencies of patient safety, nursing studies.
Summary

Patient safety represents a global public health problem. WHO Patient Safety estimates that millions of patients worldwide suffer disabling injuries or death every year due to unsafe medical practices and care. Patient safety competencies are important in professional practice, so true to install and integrate the patient safety in curriculum training of health care professionals. Mentoring and practical training is also particularly relevant to patient safety education. Research aim - expose role of practical training in developing patient safety competencies of nursing students'. The study involved general practice nursing degree program students $(N=276)$ of two Lithuanian colleges. The study was conducted using a questionnaire of Health Professional Education in Patient Safety Survey and questionnaire prepared by researcher of this study. Nursing students evaluated obtained competencies of patient safety during the theoretical lessons and practice, expressed their views about the activities of the mentor. The results revealed that the nursing students in practical training in comparison with theoretical lessons acquire fewer patient safety competencies of risk management, communication with patients, understanding of environmental factors, culture of safety, working in teams. During practical training students insufficiently acquire competencies of patient safety. Mentoring is important in developing patient safety competencies of nursing students' during practical training.

Correspondence to: simona.paulikiene@gmail.com

Gauta 2013-04-12 